\title{
岩手県南西部川尻・焼石岳地域の地すべり地形について
}

\section{Landslide Tracks in Kawajiri \& Yakeishi-dake Area southwest part of Iwate Prefecture}

\author{
多田 元 彦* \\ Motohiko TADA
}

\author{
大河原 正 文* \\ Masafumi OKAWARA
}

\author{
千田成 人* \\ Naruto CHIDA
}

\begin{abstract}
A large number of landslide track is topographically recognized in the southwestern district of Iwate prefecture, which is situated in the eastern part of the "Green Tuff region". Understanding the conditions of landslide generation, geological features in the district have been investigated by comparing the distribution map of landslides with the distribution map of gentle slopes, the rostored contour map, and the geological map. Although geologic condition of the district is somewhat peculiar since it had suffered strong mineralization in addition to the "Green Tuff" alteration, follow ings have been clarified;

1) In the case that a flat surface exists on a summit or mountainside of the mountainous area, the flat comes into a recharge area of groundwater. Therefore, where is a slope of low gradient lower in altitude than the flat, the watertable under the slope is raised and become easy to generate landslide.

2) In the area in which a potential lifting zone exists, landslides are ready to generate because unstable slopes are formed along the zone.

3) In the area where faults or fault zones area are developed, landslides with a linear headscarp, instead of a crescent-shaped scarp, are formed owing to the effect of structural controle in the fractured Neogene strata.

4) Strate including layers of muddy rock and/or acidic tuff are ready to cause landslide, because the lalyers are easy to suffer argillization.

5) In the studied district, landslides are developed well especially in the area which had suffered deep weathering, geothermal alteration and mineralization, as compared with areas without alteration.
\end{abstract}

キーワード：絩傾斜地・切峰面図・潜在的隆起帯・地域地質図

\section{1.はじめに}

奥羽脊梁山脈の東部にあたる岩手県南西部地域は，グ リンタフ地域の東部にもあたり，黒鉱型鉱床の鉱化作用 による熱水変質, 温泉等による地熱変質, 風化変質や続 成変質などにより，新第三系の地層が広く粘土化を受け た地域であって，古期地すべり地形が多数分布している 地域でもある。このように粘土化した地層であるため道 路整備による道路拡幅工事, 奥地開発による大規模林道 造成工事などでは，崖崩れがしばしば発生し，工事が難 䅆している。これらの工事などで，古期地すべり地形の 頭部載荷や末端部土留め抵抗体の除去によって, 人為的 に古期地すべりの再発を惹起せぬかと危惧されるところ でもある。大八木（1991）により指摘されている様(12)31 に, 単発的に発生した地すべり災害にはその現象発生の 要因の一つとして人為作用を無視できない場合があると

※ 岩手大学工学部
言っているが，岩手県内でも土木工事によって地すべり を誘発したものが, 数例みられる。このような人為的誘 因により，古期地すべりの滑動の再発や新しい地すべり の発生を防止するため, 地すべりの素因を環境因子4) と 物質因子 (4) の両面から明らかにする必要がある。また, 高 野（1979）も言っているように古期地すべり地の表示を することによって，人為的に再活動を発生させないよう にする5)ことも必要であろう。

このように古期地すべりの再発や新しい地すべりの発 生を防止するため, まず, この地域の地すべりの地形的 要因と地質的要因について検討を加え, この地域の「地 すべりの発生の場」を認識する必要がある。

そのために,この地域の地すべり地形分布図, 緩傾斜 地分布図, 埋谷切峰面図, 地域地質図を作成して, それ らを重㸚わせて, 地すべり地形との関係を解析するこ とにより,「地すべりの発生の場」について考察した。

この論文での検討地域の範囲は, 国土地理院発行 5 万 分の 1 地形図幅の川尻と焼石岳の北半分 (以下「当地域」 
と言う。）の範囲の地域を取り扱い，検討することとし， この地域を岩手県南西部と名付けておく。

\section{2. 地すべり地形の分布について}

広範囲の地形を立体的に観察する場合に，空中写真を 利用して地形を判読することは有効な手段なので，地す ベり地形の認定は空中写真の判読に依ることにした。使 用した空中写真は林野庁撮影のものである（表一1）。

地すべり地形の空中写真による判読マニュアルは, 今 まで多数提案されているが，米国八イウェイ調査委員会 のバァーンズ (1958) の地すべりの模式図67)を参考にし て, 地すべりの地形要素の名称を和訳した武田・今村 （1976）による地形名称と判読方法に従った ${ }^{77}$ 。ただし地 すべり崩壊の予知ではなく, 地すべり崩壊の「場」を地 形的, 地質的に取り扱うので, 滑落・移動・堆積の地す べり活動の場, 即ち滑落崖から舌端部までの地すべり活 動に擾乱された地域のみを図示することにした。形成時 期は問わないで，空中写真で地すべり地形と判断できる ものを地すべり地形と認定し, 疑わしいものについては 現地踏查をして確認した。

清水（1983）の提案している, 崖地形の不明瞭な短い リッデ, 崖地形の明瞭な小崖地形 (逆向き小崖地形), 活 断層の低断層崖などの小崖地形については, 地すべり崩 壊予知の重要な要素であるが，ここでは地すべり崩壊の 予知ではなく, 地すべり崩壊の場を扱うので，小崖地形 については地すべり地形内の小崖地形のみに限った旬10)。 土石流堆積物については, 焼石岳北西方, 三界山南方の 地すべり崩積土と崩積土砂から土石流へ発達した土石流 堆積物が連続しているので区分が困難なため，地すべり 崩積土に含めたものもある。また, 駒ヶ岳北方, 焼石岳 周辺と焼石岳の東方から南東部の崩積土にも泥流堆積物 があるが，区分が難しいので，この地域の泥流堆積物も 崩積土に含めた（図一 1 )。

当地域の地すべり地形の分布図で目につくのは，焼石 岳周辺とそれから続く南東部の石渕ダム北方の大地すべ り地形群とそれと隣り合わせの経塚山南方の大地すべり 地形群であり, それと駒ヶ岳北方の大地すべり地形群で ある。さらに南本内川中流から觜之巣上流にかけての

衰ー1 研究で使用した空中写真

\begin{tabular}{|c|c|c|c|c|c|}
\hline 揚影地区番号 & コース番号 & フイルム番号 & 撮影地区番号 & コース番号 & フイルム番号 \\
\hline \multirow[t]{2}{*}{ 山728 } & \multirow{2}{*}{ 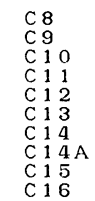 } & \multirow{2}{*}{$\begin{array}{l}7 \sim 29 \\
1 \sim 20 \\
1 \sim 21 \\
1 \sim 21 \\
2 \sim 20 \\
2 \sim 20 \\
3 \sim 22 \\
1 \sim 3 \\
3 \sim 20 \\
1 \sim 20\end{array}$} & 山728 & 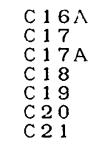 & $\begin{array}{l}1 \sim 4 \\
1 \sim 22 \\
1 \sim 3 \\
2 \sim 19 \\
2 \sim 21 \\
3 \sim 21 \\
2 \sim 18\end{array}$ \\
\hline & & & $\begin{array}{l}\text { 使用した空中 } \\
\text { 写真の枚数 }\end{array}$ & 尌 & 307 枚 \\
\hline
\end{tabular}

(1975年 林野庁撮影)
NW-SE 方向に並んだ五つの大型地すべり地形である。 その他の散在的な地すべり地形にも, NW 系, NE 系の 方向性を持って配列している傾向が読み取れる。

\section{3 . 地すべり地形と緩傾斜地について}

地すべりの発生する場は，急傾斜地より緩傾斜地の方 が多いと言われている2)。岩手県南西部の国土地理院発 行 5 万分の 1 地形図幅, 黨宿, 新町, 川尻, 六郷東半分 の地すべり地形の傾斜を調べたことがある（未公表）が， それによると表一2 のとおりであって，傾斜 $10^{\circ} \sim 20^{\circ}$ の 傾斜地にある地すべり地形は $64.5 \%$ あっあた。この地域 は本論文と重複する地域もあるため，本論文の地域と同 様の地形が発達しているものと考えられるので, この データを使用して, 当地域の地すべり地形と緩傾斜地と の関係を検討するため, 傾斜 $10^{\circ} \sim 20^{\circ}$ の緩傾斜地分布図 を作成した (図一2)。

それによると新第三系堆積前の原地形面の地形的高ま りと推定される堑ヶ森山, 牛形山, 柴沢山, 大森山には 広い山頂緩傾斜地はなく, 内因的地質作用によると考え られる前塚見山, 鬼森山, 三森山, 蟻森山, 鞍掛森山, 経塚山, 焼石岳, 笹森山には山頂平坦部があり, それか ら斜面下方へと続く緩傾斜地の緩い斜面に地すべり地形 がみられ，山頂平坦面が地すべり地形にとって重要な意 味を持つことが推定される。特に駒ヶ岳北方と，焼石岳 東方から南東方にかけては, 山頂平坦地から続く斜面下 方の緩傾斜地に大規模な地すべり地形群がみられる。

駒ヶ岳北方の大規模地すべり地形群の地形的上部には 経塚山から続く広い緩傾斜地があり，そこが地下水の涵 養地となって, 地すべり地へ地下水が供給されているも のと考えられる。

焼石岳山頂近くの緩傾斜地には, 泉水沼と湿地帯があ り, 古くから地下水の豊富な場所と考えられ，地形的下 部には地すべり湖沼群が多数みられる。この地域は地下 水面の高い地域で, 石渕夕゙ム西方には湖沼群, 北方には 地図には表示されていないが広大な湿地帯が形成されて いることが踏査で判った。

石㴊ダムから北方に続く経塚山南方の地すべり地形群 は，仙人断層が胆沢川断層，下嵐江断層おょび前川断層

表ー2 岩手県南西部の傾斜 $10^{\circ}$ 〜 $20^{\circ}$ の緩傾斜地にある地すべ り地形の個数

\begin{tabular}{|c|c|c|c|c|c|c|c|}
\hline \multicolumn{2}{|r|}{ 地形图幅名 } & 签宿 & 新町 & 川穴 & 六捤東半分 & is & 业合\% \\
\hline \multirow{2}{*}{ 垻 } & $10^{\circ}$ 末满 & 3 & 3 & 16 & 6 & 28 & 7. 8 \\
\hline & $10^{\circ}$ 以上 $15^{\circ}$ 末满 & 11 & 21 & 46 & 32 & 110 & 30.6 \\
\hline \multirow{2}{*}{ 斜 } & $15^{\circ}$ 以上 $20^{\circ}$ 未满 & 11 & 20 & 54 & 37 & 122 & 33. 9 \\
\hline & $20^{\circ}$ 以上 & 8 & 10 & 48 & 34 & 100 & 27.8 \\
\hline & st & 33 & 54 & 164 & 109 & 360 & 100.0 \\
\hline
\end{tabular}



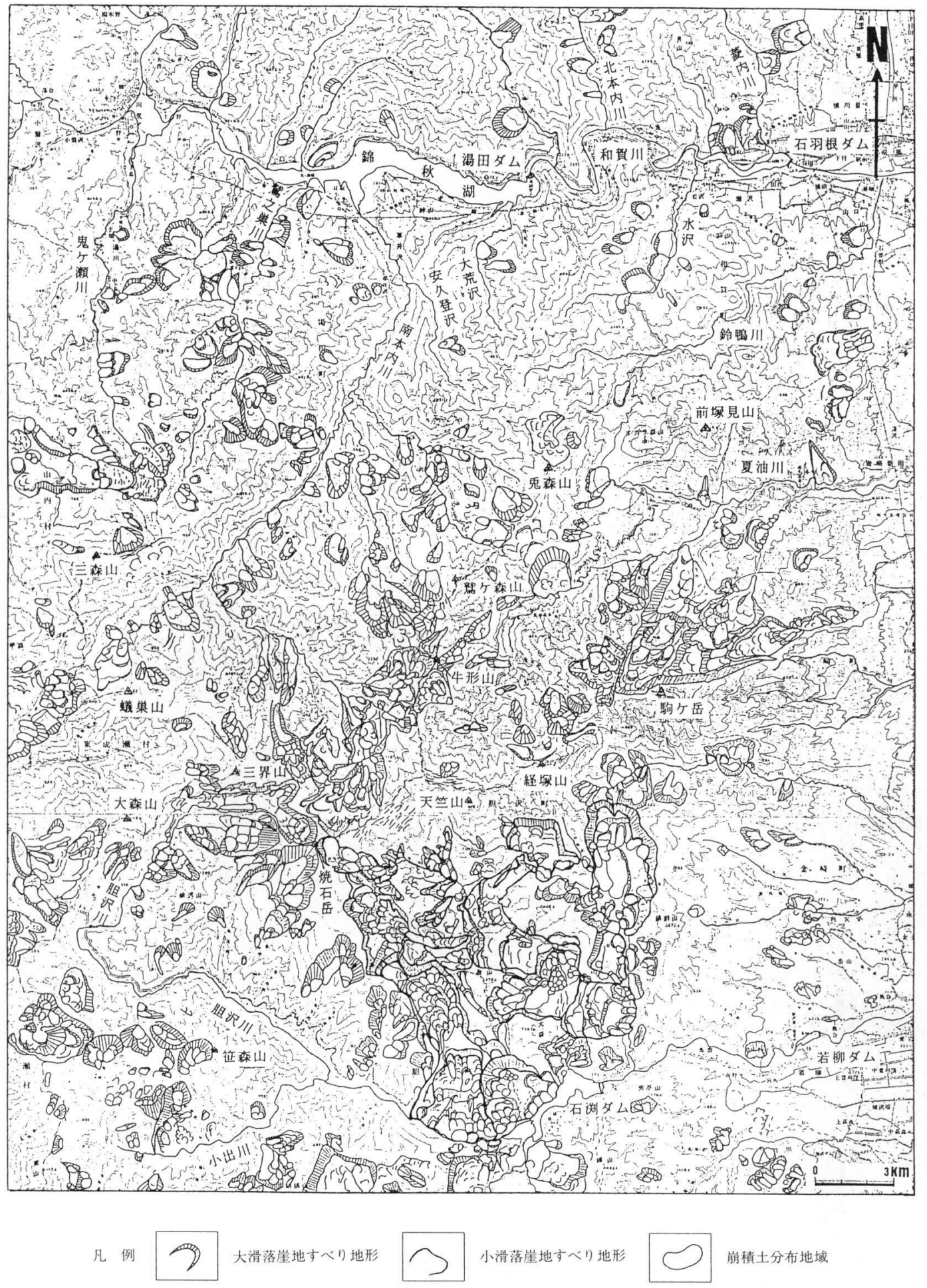

図-1川层・焼石岳地域地すべり地形分布図

に分岐する地点にあたり，地盤がブロック化されている ところで，地下水位も高く湖沼群も湿地带も形成されて いるところにある。
この様に, 大規模地すべり地形や地すべり地形群が存 在するところには, 山頂平坦地やそれに続く緩傾斜地が あり，そこが地下水の涵養地になっていて，それより地 

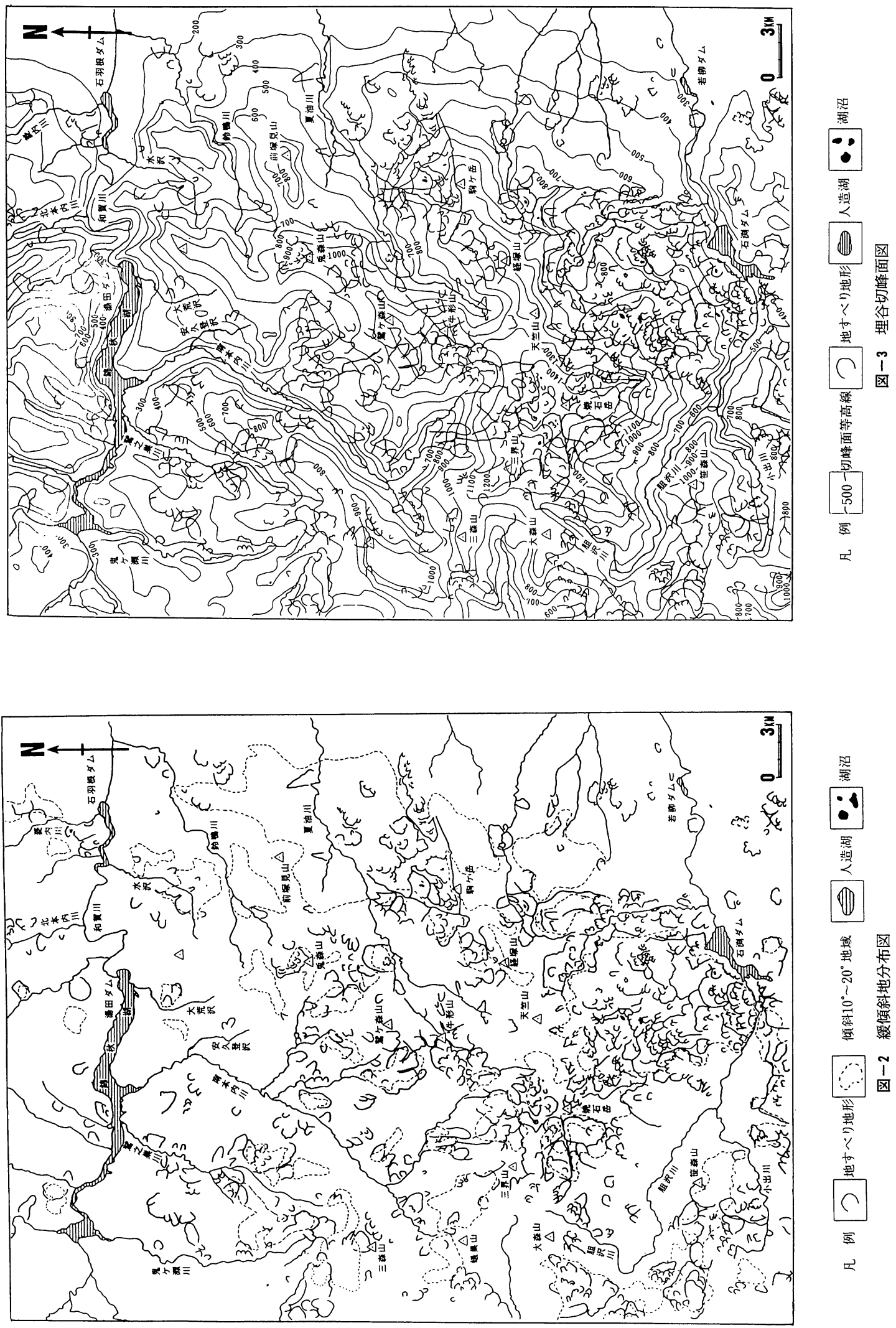

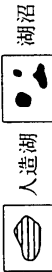

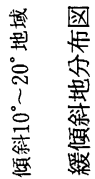


形的下部に緩傾斜地があると, 地下水が供給されて, そ の緩傾斜地に地すべりが発生するという傾向が読み取れ る。

\section{4 . 地すべり地形と埋谷切峰面図について}

地殼表層の変動に起因する斜面の不安定化は地すべり の素因の一つであり，それを認識する方法としては切峰 面図を使用する方法がある。現在の斜面形も考察の対象 とすると埋積法による切峰面図が適当と考えられ, しか も作成が簡便であるので作成, 使用することにした。

使用した埋谷切峰面図は, 国土地理院発行の 5 万分の 1 地形図を利用して, 幅 $500 \mathrm{~m}$ までの谷を埋めて作成し た当地域の埋谷切峰面図である（図一 3 ）。

作成した埋谷切峰面図を概観すると, 当地域に発達し ている水系・山系は $\mathrm{NE}$ 系, $\mathrm{NW}$ 系, N-S 系, E-W 系 の構造方向に支配されて形成されていることがさらに はっきりとする。このように構造方向が地形に表現され るのは，侵食作用によるもので，侵食作用が面的削剝か ら線的侵食へ移り変わる時に, 水系の線的侵食は新第三 系岩類の弱線部から始まるので, これらの方向の潜在的 弱線があったことになり，山系の高まりは侵食前の原地 形面の高まりか，その後の地殼変動による高まりであろ う。そのような新第三系岩類の弱線部を形成した地殼変 動は，大㭷（1989）が指摘していて，鉱脈の貫入裂罅の 方向性から NE と NW 方向のセットと NS と EW 方向 のセット1112113114) があることからも推定できる。

更に, 埋谷切峰面図から読み取れることは, E-W 方向 の和賀川の河川勾配は緩く，切峰面等高線 $300 \mathrm{~m}$ が西方 に深く切り込んでいるのに対し，同じ方向の胆沢川の河 川勾配は急であることである。河川の侵食は気候に大き く左右されると言われているが，和賀川と胆沢川とは直 線距離で約 $20 \mathrm{~km}$ しか離れておらず現在の気候条件は ほほ同じであることから，地すべり地形が形成された時 期も気候条件は同じだったと考えられる。同じだったと 考えると胆沢川の河川勾配が急であるのは胆沢川流域の 地盤隆起が考えられる。焼石岳山塊の横岳に先第三系が 分布していることから焼石岳山塊周辺は構造的隆起帯と 見ることができる。焼石岳周辺に大規模地すべり地形群 が分布しているのは構造的隆起帯であるから, 斜面の不 安定化をきたしたからであろう(図ー4)。

また, 仙人山東方から南部の経塚山東方に連なる N-S の構造方向みられるが仙人断層に依るものである。この ような地質構造方向を示す切峰面図を地すべりとの関係 からみると，焼石岳周辺とそれから続く南東斜面，経塚 山南部および駒ヶ岳北方地域に大規模な地すべり地形群 があり, 構造的隆起部の周辺には, 地すべり地形が発達 することが読み取れる。
焼石岳周辺は横岳付近に先第三系の地層が分布してい ること，潜在的な $\mathrm{NW}$ 系と $\mathrm{NE}$ 系の隆起带の交点に当 たり，山頂平坦部が広く，地下水の涵養地となり，地す べり地形が形成されたものと考えられる。焼石岳南東斜 面は流れ盤斜面を形成しているので，地すべり多発地帯 になっていると推定される。

駒ヶ岳北方は NE 系の潜在的隆起帯の幅広い緩傾斜 面を形成していて，地下水涵養地を冠頂部に持つ地域に 地すべり地形が形成されている。

尿前沢上流部の経塚山南方にある地すべり地形群は前 述のように N-S 系の仙人断層から分岐した NE 系の胆 沢川断層, 下嵐江断層, 前川断層の分岐点に当たり基礎 岩盤が破砕されて, ブロック化していて, 直線状の滑落 崖をもった地すべり地形群が発達している。

\section{5 . 地すべり地形と地質について}

当地域北部の当楽沢に NNW 方向の荒沢森背斜 ${ }^{15116)}$ があり，それに沿って古生界ベルム系の先第三系と新第 三系最下位層の大荒沢層が分布している。その背斜隆起 帯は，その東を走る仙人断層に接してから断層の西側を 南部に方向を換える。その荒沢森背斜の一部は，夏油温 泉付近で西に分肢して，鷿ケ森山と卯根倉沢上流に新第 三系最下位層の大荒沢層を分布せしめている。その背斜 隆起部の北方延長部には本屋敷南方の石英斑岩類, 川尻 東方の石英斑岩などで，先第三系の高まりを暗示させる 隆起帯を形成している。この分岐した隆起帯と荒沢森背 斜との間の山部には大石層が広く分布していて北へプラ ンヂした向斜部を形成している

一方, 仙人断層の東部の地域においては, 西部と異なっ た地層が累重していて，NS 方向の仙人断層と NNE 方 向の綱取断層とに挟まれた $\mathrm{Y}$ 字形と V字の部分には大石 層が分布し，綱取断層東部では，下位層から鉿鴨川層， 綱取層, 菱内層, 国見山酸性火山岩, 本畑層が順に分布 している。

当地域南部の地質については, 小出川流域, 胆沢川流 域さらに焼石岳山塊の横岳に先第三系が，一部花崗岩類 を伴って分布している。これらはNNE 方向の桑原岳背 斜 ${ }^{17)}$ の北北東延長部にあたっていて, 前述の荒沢森背斜 の隆起帯に続いているものと考えられている11)。

この桑原岳背斜の西翼には, 大荒沢層, 小出川層, 西 小沢層，東山流紋岩部層などが分布し，東翼には下位層 加ら，大荒沢層，小出川層，前川層，下嵐江層，瑞山層， 大平層，国見山安山岩，新期火山噴出物が分布している。

当地域の地質の概略について述べたが岩層については 表ー3を見ていただきたい。地すべり地形と地質との関 係は両者を重㸚わせて考察することとし，主たる地す べり地形ごとに検討してみたい。 

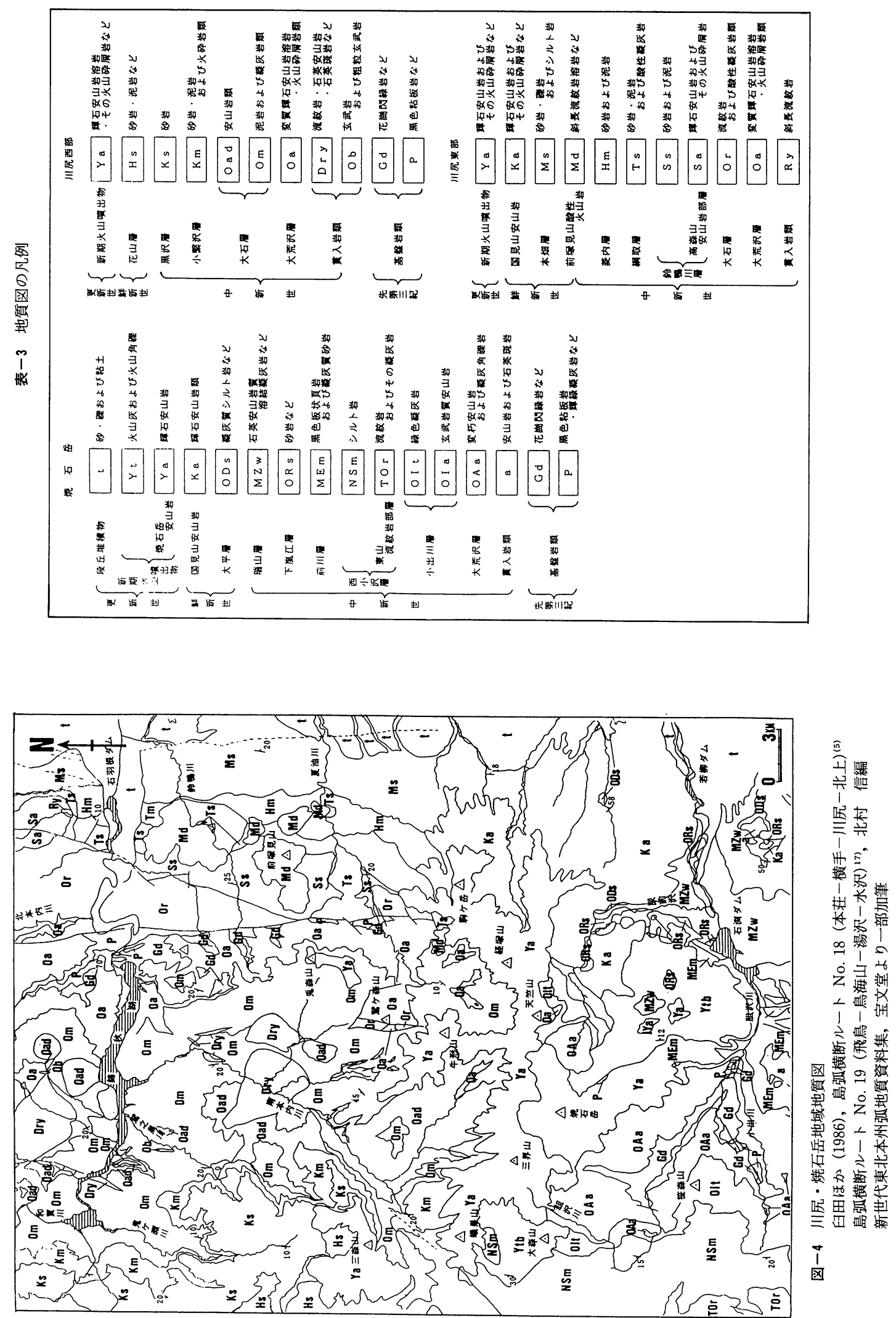
駒ヶ岳北方の地すべり地形群は, 新期火山噴出物と国 見山安山岩との境界部付近に端を発し, 北東方向に滑っ た地すべり地形群で，その北東方の地形的下部には，西 から, 綱取層, 菱内層, 本畑層が分布している。これら の構成岩相のうち, 泥岩, シルト岩および酸性凝灰岩は 粘土化し易い岩相 ${ }^{18) 19) 20121)}$ であるから地すべり地形が多 発したものと考えられる。

焼石岳北方の地すべり地形群は, 更新世の活動と考え られる焼石岳噴出物である新期火山噴出物, その下位層 は大石層上部の酸性凝灰岩および火山碟凝死岩からなっ ている。大石層上部層の酸性凝灰岩は火山性地熱作用で 変質され，粘土化されているから，それが地すべりの滑 材となって, 地すべりが発生し，地すべり地形が多数み られるものと考えられる。

焼石岳南東部とそれに続く石㴊ダム北方の地すべり地 形群は, 焼石岳に端を発し, 火山性地熱作用を受けた新 第三系の大荒沢層, 小出川層, 前川層, 下嵐江層からな り，これらの新第三系の地層の流れ盤斜面上に地すべり 地形が形成されている。その地形的下部(石㴊ダム北方) には前川層, 下嵐江層が北東方に開いた緩いセミベーズ ン構造を形成しており，その中心に，新第三系上位層の 瑞山層, 国見山安山岩, 焼石岳火山噴出物を主体とした 第四系の新期火山噴出物が堆樻している。そのセミベー ズン構造の東側の跳ねかえりの翼部が土留めの作用をし ているらしく，地すべりの活動方向が南方に向きを換え， 石㴊ダム北岸から胆沢川北岸 (左岸) に滑動方向が移つ てきている。昭和 63 年の 8 月の大雨によって, 石渕ダム の北岸の谷子沢の上流部で地すべりが発生し, 大崩壊し た傷跡がなまなましく残っている。当地区の地質は泥岩 からなる前川層と酸性凝灰岩からなる下嵐江層であり, 仙人断層から分岐した前川断層でブロック化されている 地区でもある。

経塚山南方の地すべり地形の分布している地域の地質 は, 新第三系の酸性凝灰岩を主体とした下嵐江層, 第四 系鮮新統の国見山安山岩, 焼石岳安山岩を主体とした新 期火山噴出物が広く被覆している。この地域は, ちょう ど仙人断層南方延長部にあたり, 仙人断層が胆沢川断層, 下嵐江断層および前川断層に分岐する地域に当たってい て, 新第三系がブロック化されている地域でもある。滑 落崖は直線状をなし, 連続性に富んでいるので, 胴切り 断層も含めて仙人断層に起因した滑落崖と推定される。

三森山北方の大規模地すべり地形は, 黒沢層, 一部花 山層の上に焼石岳安山岩の火山噴出物からなる新期火山 噴出物が薄く被覆したところに発生している。おそらく 酸性凝灰岩を挟在している黒沢層内に地すべりが発生し たものと推定され, 副崖面, 縦走断層がすべり方向に直 角に発達し, 波打ったようにウンジュレイト (undulate)
した模様がみられるが, バーンズの横走隆起 (transverse ridge) であろう677)。

觜之巣川上流から南本内川を経て卯根倉沢中流にかけ ての NW 方向に連なる五つの大型の地すべり地形は前 述したように，この地域の潜在的な新第三系の弱線の NE-NW 系のセットのひとつの割れ目に沿って形成さ れたものかも知れない。この五つの大型地すべり地帯の 北東側には, 前述のように基盤の盛り上がりを反映して いると考えられる石英斑岩とデイサイトの巨大な貫入岩 体が並列しているので, その貫入時に熱変質を受けて粘 土化したものかも知れない。

それら五つの地すべり地形を北西側からみると，鷿之 巣川上流の地すべり地形は小撃沢層の酸性凝死岩を伴っ た泥岩の流れ盤斜面に形成されたものである。それより 南東側にある大型地すべり地形は, 大石層上部の川尻凝 灰岩部層の酸性凝死岩内にあり, 粘土化の激しい岩層内 に形成されている。さらに南東側にある南本内川に面し た地すべり地形は, 粘土化され易い川尻凝死岩部層と岩 滑沢泥岩部層内に形成されている。それの南東方にある 地すべり地形は岩滑沢泥岩部層内の流れ盤斜面内に形成 されている。白倉山東方から牛形山西方にかけての地す べり地形は, 白倉山東方では卯根倉沢の谷頭部の地すべ りで, 焼石岳による新期火山噴出物, その下位に大石層 下部の変朽安山岩からなり, 流れ盤斜面において滑って いる。牛形山西方の地すべり地形は, 大石層下部の変朽 安山岩の上に, 焼石岳による新期火山噴出物が被覆して いるところに形成されている。

このように地すべり地形の発達している地域を, 地質 の面から検討すると地すべりを発達させている地層には 酸性凝灰岩か泥岩が挟在されているし，これらの岩層が 挟在されていない地層の地域においては, 流れ盤斜面か, 基礎岩盤が断層でブロック化されている斜面に地すべり 地形が発達している。

水沢中流と鬼森山南方, 夏油温泉北方の大型地すべり 地形については, 地すべり粘土の問題と併せて稿を改め て報告したい。

\section{6 .まとめ}

岩手県南西部の国土地理院発行 5 万分の 1 地形図の川 尻，焼石岳の地すべり地形を写真判読をして，どのよう な地学的条件の場所に地すべり地形が形成されているか 調べた結果, この地域では次の事が言えることが判った。 (1) 山地の山頂平坦地, 中腹緩傾斜地がある場合, その 緩傾斜地は地下水涵養地となり，地形的下部に緩傾斜 地があると，地下水位を高めて地すべり地を形成し易 i。

（2）基盤の古生界の地層が内座層として分布する。地層 
の配列がそれを中心に分布する。その付近の河川勾配 が急である。その付近で地すべり地形・小崖地が多数 みられる。切峰面等高線の密の部分で囲まれている， などで, 潜在的隆起帯と考えられる焼石岳周辺を中心 に放射状に, 地すべり地形が発達し, 白倉山・牛形山 周辺地域は, 焼石岳から外側に向かって滑動した地す ベり地形がみられる, 駒ヶ岳周辺地域の地すべり地形 も, 焼石岳から外側へ向かって滑動した地すべり地形 が発達している。このように, 潜在的隆起帯の存在す る地域は, 不安定斜面を形成するので, 地すべり地形 が発達している。

(3) 経塚山から尿前沢上流にかけてのように, 仙人断層 の南延長部にあたる地域には, 直線状の滑落崖・側方 崖を示す地すべり地形が発達している。断層または断 層帯が発達している地域は，新第三系の地質が破砕さ れていて, 馬蹄形の滑落崖・側方崖ではなく, 断層に 調和的な直線状の滑落崖・側方崖を持つ地すべり地形 が発達する。

(4) 風化作用・地熱作用および鉱化作用などを受けた地 域は, 受けなかった地域に比べ，新第三系が粘土化さ れており，地すべり地形の発達が著しい。地熱作用や 鉱化作用を受けなかったと考えられる前塚見山・オガ ラ森山周辺には, 地すべり地形の発達はみられない。

\section{参考文献}

1) 大八木規夫 (1991) 自然災害とその研究史, 地学雑誌, 第 10 巻第 1 号, pp. 79〜92

2 ) 高橋博・大八木規夫 - 大滝俊夫 - 安江朝光編算 (186) 斜 面災害の予知と防災, 白垔書房, p. 95

3 ) 羽田野誠一 - 大八木規夫（1986）斜面災害の予知と防災, 5 章地形的位置, 白亜書房, pp. 95 154

4) 植村武 (1982) 地すべりをどう観るか, URBAN KUBOTA 20 , pp. $52 \sim 55$
5 ）高野秀夫（1979）旧地すべり地表示の必要性について, 地すべり 56, Vol. 15, No. 4

6) Varnes, D, J (1958) Landslide type and process. in ECHEL, E, B., ed., Landslides and Engineering Practice: U. S. Natl. Reseach Council, Highway Reseach Board, Spec. Rept. 29, pp. 20 47

7) (1972) A classification on landslides. 地 すべりと対策に関する研究討論会概要, 地すべり学会, pp. $65 \sim 79$

8 ）武田裕幸・今村遼平（1976）建設技術物のための空中写 真判読, 共立出版

9 ）清水文健（1985）東北地方の大規模地すべり地形, 地す ベり，第 21 巻第 4 号, pp. 31 37

10）（1983）空中写真判読による地すべり地形の 判読と表現方法, 地すべり, 第 19 号巻第 3 号, pp. 10〜16

11）大規憲四郎（1989）鉱脈による新第三紀東北本州弧の構 造応力場復元, 地質学論集, 第 32 号, pp. 281 304

12）大沢穣（1963 a）東北地方中部における新第三紀造山運動 および鉱化作用，岩鉱，50，pp. 167〜 184

13）佐藤比呂志 - 大槻憲四郎・天野一男（1982）東北本弧に おける新生代応力場変遷, 構造地質研究会誌, No. 27, pp. $109 \sim 121$

14）佐藤比呂志（1986）東北地方中部地域（酒田－古川間） の新生代地質構造発達史, 東北大学地質古生物研究邦文 報告, No. 89, pp. 1 45

15）臼田雅郎（1986）島弧横断ルート，No. 18，第 2 巻，そ の 6 , 北村信編, 新生代東北本州弧地質資料集, pp. 18$1 \sim 18-14$

16）竹内常彦ほか 16 名（1967）昭和 41 年度広域調查報告書 「和賀雄物地域」, 通商産業省, pp. 1 21

17）臼田雅郎（1986）島弧横断ルートNo.19, 第 2 巻，その 7, 北村信編, 新生代東北本州弧地質資料集, pp. 19$1 \sim 19-15$

18）須藤俊男（1953）粘土釷物，岩波全書，pp. 152～194

19）長沢敬之助編（1967）粘土ハンドブック，技報堂出版, pp. $999 \sim 1038$

20）中村浩之（1972）黑色泥岩地帯における地すべりの土質 工学的特性, 地すべり, 第 9 巻第 2 号 $33 \sim 43$

21）水谷伸治郎，堺田直志（1974）凝灰岩の変質に関する実 験的研究, 自然災害特別研究成果, No. A-50-6, 第三 紀層の地すべり発生と予測の研究

（原稿受理日 平成 3 年 9 月 2 日） 